\title{
Protein glycosylation in sugar beet cell line can be influenced by DNA hyper- and hypomethylating agents
}

\author{
Dubravko Pavoković*, MariJana Krsnik-Rasol \\ Department of Molecular Biology, Division of Biology, Faculty of Science, \\ University of Zagreb, Horvatovac 102A, HR-10000 Zagreb, Croatia
}

\begin{abstract}
Protein glycosylation is a co- and post-translational modification that influences protein function, stability and localization. Changes in glycoprotein pattern during differentiation/dedifferentiation events exist in animal cells and DNA methylation status is closely related to the changes. However, in plant cells this relationship is not yet established. In order to verify whether such a relation exists, hypermethylating drugs 2,4-dichlorophenoxyacetic acid and hydroxyurea, or hypomethylating drug 5-azacytozine were applied to sugar beet (Beta vulgaris L.) cells during 14 days of in vitro subculture, and the glycoprotein patterns of the cells were compared. The applied drugs were not toxic, as observed from cell phenotype and by measuring growth of the control and treated cells. Hyper and hypomethylating treatments influenced the activity of enzymes related to differentiation state of the cells: peroxidases and esterases, and their isoform patterns. Electrophoretic patterns of soluble and membrane proteins were similar between control and treatments, but the treatments modified $\mathrm{N}$ - and O-linked glycoprotein patterns as visible from GNA and PNA lectin blots. This suggested that hypermethylation and hypomethylation of genomic DNA in sugar beet cells affect protein glycosylation patterns and cellular metabolism, possibly in a mechanism similar to that existing in animal cells.
\end{abstract}

Key words: cell differentiation, DNA methylation, glycoproteins, SDS-PAGE, sugar beet

Abbreviations: 2,4-D - 2,4-dichlorophenoxyacetic acid, 5-A - 5-azacytozine, GNA Galanthus nivalis agglutinin, HNO - habituated nonorganogenic cell line, HO - habituated organogenic cell line, HU - hydroxyurea, $\mathbf{N}$ - normal cell line, PNA - peanut agglutinin SDS-PAGE - sodium dodecyl sulphate polyacrylamide gel electrophoresis

\section{Introduction}

Protein glycosylation is the gradual attachment of different carbohydrates to a nascent protein carried out in endoplasmic reticulum and Golgi apparatus. Carbohydrates may vary but the common ones attached are mannose, glucose, galactose, $\mathrm{N}$-acetylgalactosamine, xylose, fucose, and N-neuraminic acid or, sialic acid (SPIRo 2002). The attachment site is

* Corresponding author, e-mail: dubravko@zg.biol.pmf.hr

Copyright $^{\circledR} 2011$ by Acta Botanica Croatica, the Faculty of Science, University of Zagreb. All rights reserved. 
on the specific asparagine (N-linked glycosylation) or on serine/threonine residues (O-linked glycosylation). In animal tissues, $\mathrm{N}$ - and $\mathrm{O}$-linked glycans are involved in a number of normal and aberrant physiological functions such as cell adhesion, signal transduction, protein conformational stabilization and targeting, protease resistance, charge umbrella, water-binding capacity, cellular recognition and developmental regulation (for a review see VARKI 2008). Changes in protein glycosylation are observed during normal cell and tissue differentiation but also during malignant transformation of animal cells (PERACAULA 2007, HeDLund et al. 2008). Epigenetics, like DNA methylation level, has important roles in this process by affecting activities of protein glycosyltransferases (KANNAGI 2004, KAWAMURA et al. 2008, KANNAGI et al. 2010).

In plants, $\mathrm{N}$ - and $\mathrm{O}$-linked glycans strongly influence protein conformation, stability, biological activity (RAYON et al. 1998). The glycan part of the protein serves as a subcellular localization signal (FITCHETTE et al. 2007). Disruption of normal protein glycosylation severely affects plant development causing embryo lethality, severe defects in cell wall biogenesis or plant growth retardation (VITALE 2001, KLEIN et al. 2006). Protein glycosylation is influenced by metabolic changes occurring in the tissues, such as acclimatization to in vitro conditions (BALEN et al. 2008) or by the developmental state and the age of the plants (ELBERS et al. 2001). However, it is not known whether using agents that change the DNA methylation level in plant cells will change protein glycosylation, as it does in animal cells.

Sugar beet cell lines have been thoroughly investigated in culture for more than 20 years and are established as a suitable model for studies of plant metabolism and cell differentiation (DE GreEF and JACobs 1979, CAuseviC et al. 2005, CAuseviC et al. 2006). The N (normal) line is photosynthetic, differentiated but not organogenic. The HO (habituated organogenic) line is photosynthetic, differentiated and organogenic, shoot-producing. The HNO (habituated non-organogenic) is etiolated, and dedifferentiated. The cell lines, coming from the same mother plant, have distinct genomic DNA methylcytosine content, cell differentiation level and morphology. Using hypomethylating drugs like 5-azacytozine (5-A) or hypermethylating drugs like 2,4-dichlorophenoxyacetic acid (2,4-D) and hydroxyurea (HU) it is possible to affect DNA methylation levels, modify metabolism, phenotype and ultimately differentiation state of the cells (CAUSEVIC et al. 2005).

This model system seemed suitable to test whether externally applied agents that modify DNA methylation levels will affect $\mathrm{N}$ - and O-glycosylation patterns of proteins in sugar beet $\mathrm{N}$ cell line. As a result of previous observations, the $\mathrm{N}$ line was chosen because its DNA cytosine methylation level is normally at $22 \%$ and it is between $\mathrm{HO}$, at $18 \%$, and HNO, at 29\% (CAUSEVIC et al. 2005), which should give more flexibility in changes of methylation level and differentiation status during the experiment. Both, hypermethylating and hypomethylating treatments induced cell dedifferentiation in the $\mathrm{N}$ line, causing a part of the cells to change their morphology and look like HNO cells, white and very friable (CAUSEvic et al. 2005).

A suitable way to discern changes in metabolism and differentiation state indirectly is to monitor activity and isozyme patterns of certain enzymes. Peroxidases but also esterases are markers of cellular or organ differentiation (KRSNIK-RASOL et al. 1999). In sugar beet, peroxidase activities were related to the DNA methylcytosine percentage (CAUSEVIC et al. 2005). In cactus Mammillaria gracilis, as well as in cotton embryos, the number of esterase isoforms depended on the morphological state of the tissue (BALEN et al. 2003, HILAIRE et al. 2007). 
In this work, the $\mathrm{N}$ cells were treated with 5-A, 2,4-D and HU during the period of one subculture. Toxicity of the treatments was evaluated by measurement of the growth of the cells. Changes in metabolism and protein glycosylation pattern were observed, which could be related to the action of the drugs used.

\section{Material and methods}

\section{Plant material, growth conditions and treatments}

The cell lines of sugar beet originate from the same mother plant and were cultivated in vitro on a solid PG0 nutrient media (NEGRUTIU et al. 1975, DE GREEF and JACOBS 1979). The $\mathrm{N}$ cell line was grown in a growth chamber at $22^{\circ} \mathrm{C}$ under a $16 \mathrm{~h}$ photoperiod $(80 \mu \mathrm{mol}$ photons $\mathrm{m}^{-2} \mathrm{~s}^{-1}$ ). For treatments, the toxicity of the chemicals was evaluated first using concentrations in the range of $25-200 \mu \mathrm{mol} \mathrm{L}^{-1}$ of $2,4-\mathrm{D}, 100-1000 \mu \mathrm{mol} \mathrm{L}{ }^{-1}$ of $5-\mathrm{A}$, and 200-400 $\mu \mathrm{mol} \mathrm{L}{ }^{-1}$ of HU (all purchased from Sigma, Germany) (data not shown). The chemicals were added as sterile solutions immediately before casting the nutrient medium in Petri dishes. Based on the obtained results we analyzed the enzyme activity and glycoprotein pattern in plant material upon treatment with optimal concentrations of chemical agents: $2,4-\mathrm{D}\left(100 \mu \mathrm{mol} \mathrm{L}^{-1}\right)$, and $\mathrm{HU}\left(200 \mu \mathrm{mol} \mathrm{L}^{-1}\right)$ that resulted in maximal increase in fresh weight of cells in comparison to control, as well as 5-A $\left(200 \mu \mathrm{mol} \mathrm{L}^{-1}\right)$ that minimally inhibited the plant growth in comparison to control. Tissue samples were collected at days 7 , and 14 of subculture, weighted for growth analysis, frozen in liquid nitrogen and stored at $-80^{\circ} \mathrm{C}$.

\section{Protein extracts and enzyme analysis}

Sugar beet N tissue was grinded in a bead mill Retsch 200 (Retsch GMBH, Germany) for $2 \mathrm{~min}$ at $30 \mathrm{~Hz}$. Tissue was supplemented with ice-cold potassium phosphate buffer $\mathrm{pH}$ 7.0 or Tris- $\mathrm{HCl}$ buffer $\mathrm{pH}$ 7.4. Crude protein extracts were clarified by centrifugation at $20000 \mathrm{x} \mathrm{g}$ for $20 \mathrm{~min}$ and again at $20000 \mathrm{x} \mathrm{g}$ for $10 \mathrm{~min}$, all at $4{ }^{\circ} \mathrm{C}$. Protein content of supernatant was determined according to BRADFORD (1976). Guaiacol peroxidase activity of protein extracts was determined spectrophotometrically (ATI UNICAM UV4, Cambridge, UK) at room temperature $\left(25^{\circ} \mathrm{C}\right)$ by measuring the increase in absorbance at 470 $\mathrm{nm}$. The test solution was prepared after SIEGEL and GALSTON (1967), with $5 \mathrm{mmol} \mathrm{L}^{-1}$ guaiacol and $5 \mathrm{mmol} \mathrm{L} \mathrm{m}^{-1} \mathrm{H}_{2} \mathrm{O}_{2}$, in a $100 \mathrm{mmol} \mathrm{L}^{-1}$ potassium phosphate buffer $\mathrm{pH}$ 7.0. A broad spectrum esterase substrate 1-naphthylacetate was used for esterase activity measurement according to BURLINA and GALZIGNA (1972). Esterase activity was determined spectrophotometrically at room temperature $\left(25^{\circ} \mathrm{C}\right)$ by measuring the increase in absorbance at $322 \mathrm{~nm}$. The reaction medium contained $1.5 \mathrm{~mL}$ of $100 \mathrm{mmol} \mathrm{L}^{-1}$ Tris- $\mathrm{HCl} \mathrm{pH} 7.4$ and $30 \mu \mathrm{L}$ of $100 \mathrm{mmol} \mathrm{L}^{-1}$ 1-naphthylacetate dissolved in methanol. For each measurement $150 \mu \mathrm{L}$ of crude extract was used. Measurements were performed every 15 seconds over a three min period. The esterase activities were corrected for spontaneous hydrolysis of 1-naphthylacetate. The blank contained only the buffer and 1-naphthylacetate. The activities of peroxidases and esterases were expressed as a percentage of the control. Experiments were performed at least in triplicates. 
Statistical analysis of enzyme activities by means of one-way ANOVA was performed using embedded functions in Sigmaplot 12 software (Systat Software Inc. CA, USA) and results were considered significant when $\mathrm{p}<0.05$.

\section{Protein gel electrophoresis}

Soluble proteins were extracted according to PAVOKOvić et al. (2007). Pellet left after extraction of soluble proteins was washed three times in extraction buffer and then $0.5 \mathrm{~mL}$ of extraction buffer containing $130 \mathrm{mmol} \mathrm{L}^{-1}$ Tris- $\mathrm{HCl} \mathrm{pH} \mathrm{6.8,} \mathrm{4.6 \%} \mathrm{(w/v)} \mathrm{sodium} \mathrm{dodecyl}$ sulphate (SDS), $16 \%$ glycerol and $0.6 \%$ (w/v) dithiothreitol, preheated to $80{ }^{\circ} \mathrm{C}$ was added to the pellet to disrupt the membranes and to extract membrane proteins. Homogenates were incubated at $80{ }^{\circ} \mathrm{C}$ for $10 \mathrm{~min}$ on a shaker, and clarified by centrifugation at $20000 \mathrm{x} \mathrm{g}$ for $10 \mathrm{~min}$. Supernatants were decanted and another $0.5 \mathrm{~mL}$ of the same pre-heated SDS-extraction buffer was added to the pellet. Samples were incubated again under the same conditions as above. After centrifugation, supernatants were pooled and used in subsequent electrophoretic analyses as membrane protein fraction.

SDS polyacrylamide gel-electrophoresis of protein samples was carried out in a vertical gel system in $12 \%$ polyacryamide gels with the buffer system of LAEMMLI (1970). Proteins were visualized using Coomassie Brilliant Blue stain. Soluble protein samples were also separated in native conditions by vertical electrophoresis in $8-18 \%$ polyacrylamide gradient gels with the same buffer system, but without SDS. In-gel activity of peroxidase and esterase isoforms were performed as described earlier (BALEN et al. 2003), based on the methods developed by SIEGEL and GALSTON (1967).

\section{Electroblot and lectin hybridization}

Following SDS-PAG electrophoresis, proteins were electroblotted onto nitrocellulose membrane for $1 \mathrm{~h}$, at $60 \mathrm{~V}$. To detect glycoconjugates, lectins from Galanthus nivalis (GNA) and peanut (PNA) were used. Lectins were conjugated with digoxigenin (DIG), and anti-DIG alkaline phosphatase was used as a secondary anti-body (Roche Diagnostics $\mathrm{GmbH}$, Germany). Site of the hybridization was visualized using BCIP/NBT as a substrate for the alkaline phosphatase.

Gels and membranes were scanned on a flatbed scanner (HP, USA) at 300 DPI, and protein and glycoprotein expression profiles were analyzed by UTHSCSA Image Tool v3.0 (TX, USA).

\section{Results}

Here we report that the use of externally applied drugs HU, 2,4-D and 5-A, which change DNA methylation level, affects glycoprotein patterns in sugar beet $\mathrm{N}$ cell line. Eventual toxicity of the DNA modifying treatments was verified by comparing cell growth (Fig. 1). Cells treated with $200 \mu \mathrm{mol} \mathrm{L}{ }^{-1} \mathrm{HU}$ proliferated similarly to the control, while cells treated with $100 \mu \mathrm{mol} \mathrm{L}{ }^{-1}$ 2,4-D and $200 \mu \mathrm{mol} \mathrm{L}{ }^{-1}$ 5-A proliferated slowly but without any apparent necrosis or growth arrest. However, a concentration of $200 \mu \mathrm{mol} \mathrm{L}^{-1}$ of 2,4-D in the medium was toxic: growth stopped and cells quickly became necrotic (data not shown). 


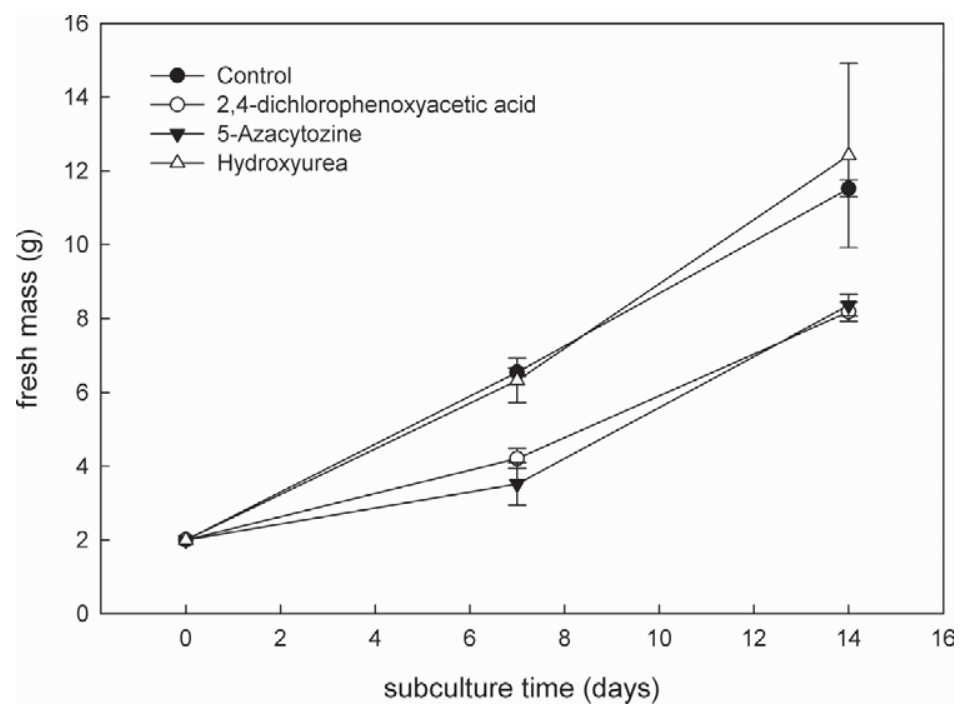

Fig. 1. Growth of the sugar beet $\mathrm{N}$ cell line treated with hyper- or hypomethylating drugs. Data are mean \pm SE for three replicates.

The treatments had a profound effect on cellular metabolism, which was visible from measurements of esterase and peroxidase activities, and by in-gel visualization of their isoforms at day 7 and day 14 of the subculture (Fig. 2). Esterase activity was estimated using 1-naphtylacetate as a substrate (Fig. 2b). When compared with the control, all treatments significantly increased esterase activity at days 7 and 14 of the subculture. After native electrophoresis, in-gel staining of esterases showed five isoforms: E1-E5 (Fig. 2a). Treatments differentially induced esterase isoforms, but the changes of the signal of isoforms E3-E5 were the most remarkable. Isoform E5 was particularly induced by the 2,4-D and 5-A treatments. The guaiacol peroxidase activities were also modified by treatments in both data points (Fig. 2c). At day 7, significant decrease in activity was observed in 5-A and HU treated cells. At day 14, 2,4-D and 5-A significantly decreased peroxidase activity, but the HU treatment significantly increased its activity. However, in-gel activity of peroxidases could not be obtained under the same conditions, probably due to the isoelectric nature of the peroxidase isoforms.

Application of agents that modify DNA methylation level changed glycosylation patterns, which was observed by differential binding of GNA and PNA lectins to glycoproteins. Expression of soluble and membrane proteins remained unchanged, as shown by Coomassie Brilliant Blue staining (Fig. 3a, b). We observed that fewer soluble proteins were glycosylated than membrane proteins (Fig. 3c-f), which is in accord with the fact that most glycosylated proteins are destined to plasma membranes and to the extracellular space. In soluble protein fraction, no differences were observed in the glycosylation pattern of high-mannose glycans (Fig. 3c). In the membrane fraction (Fig. 3d), a glycoprotein of 20 kDa was induced at days 7 and 14 with 2,4-D and at day 7 with HU. At day 14 HU the signal of this glycoprotein was lost, together with that of $22 \mathrm{kDa}$. In soluble protein fraction PNA lectin revealed two O-linked glycoproteins with sizes around 40 and $42 \mathrm{kDa}$ (Fig. 3e). 

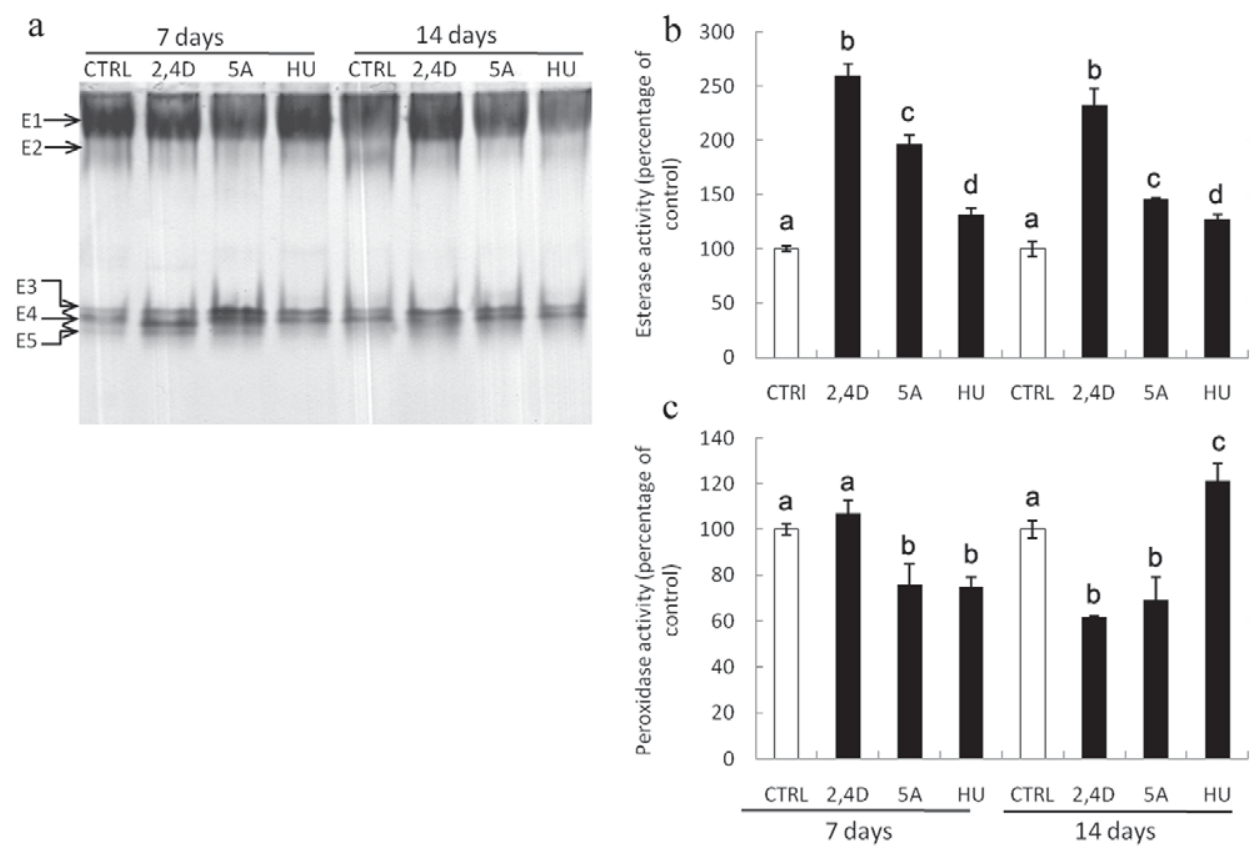

Fig. 2. The effect of hyper- or hypomethylating drugs on esterase and peroxidase activities and its isoenzyme patterns in sugar beet $\mathrm{N}$ line. a - Esterase izoenzyme patterns visualized with 1-naphtylacetate after native electrophoresis of $100 \mathrm{mg}$ of protein samples in a $12 \%$ polyacrylamide gel; $\mathbf{b}$ - Esterase activities expressed as a percentage of control; $\mathbf{c}$ - Peroxidase activities expressed as a percentage of control; CTRL - control; 2,4D - 2,4-dichlorophenoxyacetic acid; 5-A - 5-azacytozine; $\mathbf{H U}$ - hydroxyurea. Data are mean $\pm \mathrm{SE}$ for at least three replicates. Asterisks denote statistically different enzyme activity at $\mathrm{p}<0.05$.

At 7 days all treatments decreased the signal from the $42 \mathrm{kDa}$ glycoprotein. At day 14, in the control and in the 2,4-D and 5-A the 40 and $42 \mathrm{kDa}$ glycoproteins were not detected; however, with HU, both of those glycoproteins reappeared. In the membrane fraction PNA lectin also revealed more O-linked glycoproteins than in the soluble fraction. Induction of a $18 \mathrm{kDa}$ glycoprotein appeared after 7 and 14 days in cells treated with 2,4-D. A 40 and 20 $\mathrm{kDa}$ glycoproteins were downregulated by $5-\mathrm{A}$ and $\mathrm{HU}$ at 14 days of the treatment (Fig. 3f).

\section{Discussion}

Here we have shown that the application of chemicals that change genomic DNA methylation level affected cellular metabolism and glycosylation of cellular and membrane proteins in sugar beet cells. Significant genomic DNA hypermethylation was successfully induced in several plant species, including sugar beet, with 2,4-D and HU, and DNA hypomethylation with 5-A, with concentrations similar to or higher than those applied here, and without any apparent toxicity (CAUSEVIC et al. 2005, YАмАмото et al. 2005). 

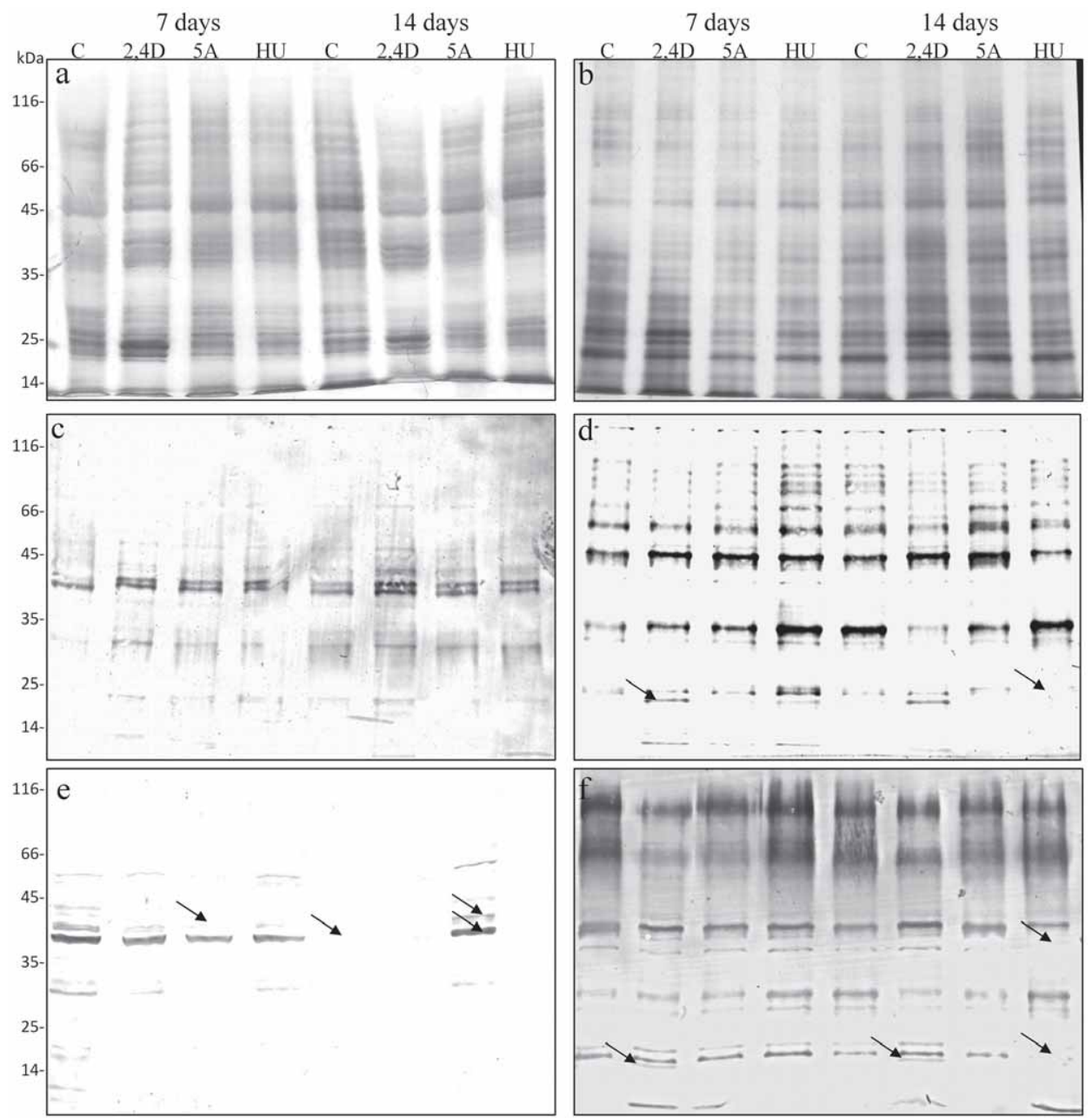

Fig. 3. Metabolic changes induced by hyper- or hypomethylating drugs affect glycosylation pattern of cellular and membrane proteins in sugar beet $\mathrm{N}$ line. Proteins were electroblotted onto nitrocellulose membrane and different carbohydrates as glycoconjugates were detected using plant lectins. $\mathbf{a}-\mathrm{CBB}$ stained gel of soluble proteins; $\mathbf{b}-\mathrm{CBB}$ stained gel of membrane proteins; $\mathbf{c}$ - high-mannose glycoproteins detected with GNA lectin in soluble protein fraction; $\mathbf{d}$ - high-mannose glycoproteins detected with GNA lectin in membrane protein fraction; e - O-linked glycoproteins detected with PNA lectin in soluble protein fraction; $\mathbf{f}-$ O-linked glycoproteins detected with PNA lectin in membrane protein fraction. Numbers on the left show protein size in $\mathrm{kDa}$. $\mathbf{C}$ - control; 2,4D - 2,4-dichlorophenoxyacetic acid; 5-A 5-azacytozine; HU - hydroxyurea.

Since the morphological changes in $\mathrm{N}$ cells were minimal after treatments, as an indirect proof of changes in differentiation status we monitored the changes of activities of peroxidases and esterases. Here we measured statistically significant differences in activities of esterases and peroxidases after the treatments. These enzymes have been established 
as biochemical markers of cell differentiation and morphogenesis in plants (KRSNIK-RASOL et al. 1999, BALEN et al. 2003, PASSARDi et al. 2005). Peroxidase activity can be affected by DNA methylation status, which was already reported in Bryonia dioica internodes and in sugar beet cells, both treated with DNA hypo- or hypermethylating agents (GALAUD et al. 1993, CAUSEVIC et al. 2005). While CAUSEVIC et al. (2005) reported an increase in activity of guaiacol peroxidases after treatment with 5-A and a decrease after HU treatment, we reported here the opposite situation. The cause for such discrepancy could lie in different extraction methods, which could yield different peroxidase isoforms. It is known that there are a huge number of peroxidases in plant cells, each with a specific function assigned. For example, in Arabidopsis, there are 73 predicted peroxidase genes (OLIVA et al. 2009).

We also observed in native gels that esterase isoforms, and especially isoform E5, was more intensively colored with the treatments 5-A and HU. It is tempting to propose that the E5 isoform might be an indirect proof of changes of DNA methylation. Changes in the number and intensity of esterase isoforms occur when tissues of identical origin change their morphological status, as in Mammillaria plant, callus or tumor tissues (BALEN et al. 2003). Similarly, the number of esterase isoforms increased when cotton cells differentiated during embryogenesis (HILAIRE et al. 2007). It seems that the changes in activity of peroxidases and esterases reflected metabolic changes caused by the drugs used.

To detect changes in glycoprotein patterns, GNA and PNA lectins were used. GNA lectin binds to the terminal mannose of the N-glycans (SHIBUYA et al. 1988), and PNA specifically recognizes the Galactosy $1 \beta-1,3-N$-acetyl galactosamine sequence present in the core unit of O-glycans (GOLDSTEIN and HEYES 1978). Using these lectins it was possible to detect a large number of $\mathrm{N}$ - and $\mathrm{O}$-linked glycans and make a proper screening of changes in the glycosylation pattern.

In mammalian cells a possible explanation behind altered protein glycosylation was proposed in which the DNA methylation and/or histone deacetylation alter cellular carbohydrate metabolism, sugar transportation and expression of genes for sugar transporters (KANNAGI 2004). Subsequent experiments on gastrointestinal cancer cells revealed that inhibition of DNA methylation with 5-aza-2'-deoxycytidine silences some genes belonging to the glycosyltransferase and glycosidase families (KAWAMURA et al. 2008). This repressed aberrant glycosylation and cancer-associated carbohydrate antigens. In plants, 2,4-D can strongly modulate activity of some glycosyltransferases and induce glycosylation of biological molecules such as scopoletin and quercetin in tobacco and Vitis sp. cell cultures, respectively (KOKUBO et al. 2001, TAGUCHI et al. 2001). It remains to be seen whether application of 2,4-D affects the activity of protein glycosyltransferases. In carrot 2,4-D transiently induced DNA methyltransferase gene Met $1-5$ before the induction of somatic embryogenesis in epidermal cells (YАмАмото et al. 2005). Hydroxyurea, like the 2,4-D increases DNA methylation level, but by a mechanism that involves inhibition of the enzyme ribonucleotide reductase (KOÇ et al. 2004). This is most probably different mechanism, than the one by which 2,4-D acts on DNA methylation, which could explain the differences in glycoprotein pattern after treatments with these two different DNA hypermethylators.

In plants, changes in glycosylation pattern are observed during developmental processes in which cell differentiation is affected, like embryogenesis in pumpkin or establishment of in vitro tissues of cactus Mamillaria sp. (LELJAK-LEVANIĆ et al. 2011, BALEN et al. 
2005, BALEN et al. 2008). In Mamillaria sp. the changes lead to the appearance of novel protein $\mathrm{N}$-glycan structures (BALEN et al. 2005). Unfortunately, the function of these glycan structures on protein stability and location is not known. A specific protein expression pattern after establishment and/or maintenance of the differentiation state in plant cells is enabled by the changes in DNA methylation status, most probably by the methylation of promoters regions (BERDASCO et al. 2008).

In conclusion, we have shown that chemicals that change the methylation status of genomic DNA affect cellular metabolism and glycosylation protein pattern in sugar beet $\mathrm{N}$ cell line, strengthening the relationship between DNA methylation level and protein glycosylation. This process could be similar to the process already reported in mammalian cells. By following an approach similar to that used for mammalian cells, e.g. bisulfite $\mathrm{PCR}$, it could be possible to pinpoint specific promoters that are differentially methylated during changes in genomic DNA methylation, and to gain more information how DNA methylation status controls protein glycosylation in plants. Additionally, research into protein glycosylation in plants presents an opportunity to identify protein biomarkers of the specific developmental state of a cell or a tissue.

\section{Acknowledgements}

Financial support for this work was provided by the Ministry of Science, Education and Sports of the Republic of Croatia (project No. 119-1191196-1200).

\section{References}

BAlen, B., Krsnik-RAsol, M., SimeOn-Rudolf, V., 2003: Isoenzymes of peroxidase and esterase related to morphogenesis in Mammillaria gracillis Pfeiff. tissue culture. Journal of Plant Physiology 160, 1401-1406.

Balen, B., Zamfir, A., Vakhrushev, S. Y., Krsnik-Rasol, M., Peter-Katalinić, J., 2005: Determination of Mammillaria gracillis N-glycan patterns by ESI Q-TOF mass spectrometry. Croatica Chemica Acta 78, 463-477.

Balen, B., Peharec, P., Krsnik-Rasol, M., 2008: Developmentally specific soluble and membrane proteins and glycoproteins in Mammillaria gracillis Pfeiff. (Cactaceae) tissue culture. Acta Botanica Croatica 67, 221-227.

Berdasco, M., Alcázar, R., García-Ortiz, M. V., Ballestar, E., Fernández, A. F., Roldán-Arjona, T., Tiburcio, A. F., Altabella, T., Buisine, N., Quesneville, H., Baudry, A., Lepiniec, L., Alaminos, M., Rodríguez, R., Lloyd, A., Colot, V., Bender, J., Canal, M. J., Esteller, M., Fraga, M. F., 2008: Promoter DNA hypermethylation and gene repression in undifferentiated Arabidopsis cells. Plos One 3, e3306.

BRADFORD, M. M., 1976: A rapid and sensitive method for the quantitation of microgram quantities of protein utilizing the principle of protein-dye binding. Analytical Biochemistry $72,248-254$.

Burlina, A., Galzigna, L., 1972: A new and simple procedure for serum arylesterase. Clinical Chimica Acta 39, 255-257. 
Causevic, A., Delaunay, A., Ounnar, S., Righezza, M., Delmotte, F., Brignolas, F., HaGÈGe, D., MAury, S., 2005: DNA methylating and demethylating treatments modify phenotype and cell wall differentiation state in sugarbeet cell lines. Plant Physiology and Biochemistry 43, 681-691.

Causevic, A., Gentil, M. V., Delaunay, A., El-Soud, W. A., Garcia, Z., Pannetier, C., Brignolas, F., HagÈge, D., Maury, S., 2006: Relationship between DNA methylation and histone acetylation levels, cell redox and cell differentiation states in sugarbeet lines. Planta 224, 812-827.

DE GREEF, W., JACOBS, M., 1979: In vitro culture of the sugarbeet: Description of a cell line with high regeneration capacity. Plant Science Letters 17, 55-61.

Elbers, I. J. W., Stoopen, G. M., Bakker, H., Stevens, L. H., Bardor, M., Molthoff, J. W., Jordi, W. J. R. M., Bosch, D., LOMmen, A., 2001: Influence of growth conditions and developmental stage on $\mathrm{N}$-glycan heterogeneity of transgenic immunoglobulin $\mathrm{G}$ and endogenous proteins in tobacco leaves. Plant Physiology 126, 1314-1322.

Fitchette, A. C., Dinh, O. T., FAye, L., Bardor, M., 2007: Plant proteomics and glycosylation. In: Thiellement, H., Zivy, M., Damerval, C., Méchin, V., (eds.), Methods in molecular biology, 355. Plant proteomics methods and protocols 317-342. Humana Press, Totowa, New Jersey.

Galaud, J. P., Gaspar, T., Boyer, N., 1993: Effect of anti-DNA methylation drugs on growth, level of methylated DNA, peroxidase-activity and ethylene production of Bryonia dioica internodes. Physiologia Plantarum 87, 528-534.

Goldstein, I. J., HAYES C. E., 1978: The lectins: carbohydrate-binding proteins of plants and animals. Advances in Carbohydrate Chemistry and Biochemistry 35, 127-340.

Hedlund, M., NG, E., VArki, A., VARKi, N. M., 2008: a 2-6-linked sialic acids on $\mathrm{N}$-glycans modulate carcinoma differentiation in vivo. Cancer Research 68, 388-394.

Hilaire, K. T., Daouda, K., Michel, Z., Justin, K. Y., 2007: Esterase isoenzymes are linked to embryogenic structures induction in cotton cell suspension cultures. African Journal of Agricultural Research 2, 394-398.

KANNAGI, R., 2004: Molecular mechanism for cancer-associated induction of sialyl Lewis $\mathrm{X}$ and sialyl Lewis A expression-The Warburg effect revisited. Glycoconjugate Journal 20, 353-364.

Kannagi, R., Sakuma, R., Miyazaki, K., Lim, K.-T., Yusa, A., Yin, J. Izawa, M., 2010: Altered expression of glycan genes in cancers induced by epigenetic silencing and tumor hypoxia: Clues in the ongoing search for new tumor markers. Cancer Science 101, $586-593$.

Kawamura, Y. I., Toyota, M., Kawashima, R., Hagiwara, T., Suzuki, H., Imai, K., Shinomura, Y., Tokino, T., Kannagi, R., DoHI, T., 2008: DNA hypermethylation contributes to incomplete synthesis of carbohydrate determinants in gastrointestinal cancer. Gastroenterology 135, 142-151.

Klein, E. M., Mascheroni, L., Pompa, A., Ragni, L., Weimar, T., Lilley, K. S., Dupree, P., VITALE, A., 2006: Plant endoplasmin supports the protein secretory pathway and has a role in proliferating tissues. The Plant Journal 48, 657-673. 
Koç, A., Wheeler, L. J., Mathews, C. K., Merrill, G. F., 2004: Hydroxyurea arrests DNA replication by a mechanism that preserves basal dNTP pools. Journal of Biological Chemistry 279, 223-230.

Kokubo, T., Ambe-Ono, Y., Nakamura, M., Ishida, H., Yamakawa, T., Kodama, T., 2001: Promotive effect of auxins on UDP-glucose: Flavonol glucosyltransferase activity in Vitis sp. cell cultures. Journal of Bioscience and Bioengineering 91, 564-569.

Krsnik Rasol, M., ČIPČIĆ, H., HAGËGE, D., 1999: Isoesterases related to cell differentiation in plant tissue culture. Chemico-Biological Interactions 119-120, 587-592.

LAEMMLI, U. K., 1970: Cleavage of structural proeins during the assembly of the head of bacteriophage T4. Nature 227, 680-685.

Leljak-Levanić, D., ČipČić Paljetak, H., Uzelac, L., Mihaljević, S., Bauer, N., KrsniK-RASOL, M., JELASKA, S., 2011: Extracellular glycoproteins in embryogenic culture of pumpkin (Cucurbita pepo L.). Food Technology and Biotechnology 49, 120-127.

Negrutiu, I., BeEftink, F., JACOBS, M., 1975: Arabidopsis thaliana as a model system in somatic cell genetics I. Cell and tissue culture. Plant Science Letters 5, 293-304.

Oliva, M., Theiler, G., Zamocky, M., Koua, D., Margis-Pinheiro, M., Passardi, F., DunAND, C., 2009: PeroxiBase: A powerful tool to collect and analyse peroxidase sequences from Viridiplantae. Journal of Experimental Botany 60, 453-459.

Passardi, F., Cosio, C., Penel, C., Dunand, C., 2005: Peroxidases have more functions than a Swiss army knife. Plant Cell Reports 24, 255-265.

Pavoković, D., Šola, I., HAgËGe, D., KRSNIK-RASOl, M., 2007: Sugar-induced changes in cellular and extracellular protein and glycoprotein patterns of sugarbeet cell lines. Acta Botanica Croatica 66, 127-134.

PeracAula, R., 2007: Altered glycosylation in tumour proteins: Biological implications. Afinidad 64, 346-355.

RAyOn, C., Lerouge, P., FAYE, L., 1998: The protein N-glycosylation in plants. Journal of Experimental Botany 49, 1463-1472.

Shibuya, N., Goldstein, I. J., Vandamme, E. J. M., Peumans, W. J., 1988: Binding-properties of a mannose-specific lectin from the snowdrop (Galanthus-nivalis) bulb. Journal of Biological Chemistry 263, 728-734.

Siegel, B. Z., Galston, A. W., 1967: The isoperoxidases of Pisum sativum. Plant Physiology 42, 221-226.

SPIRO, R. G., 2002: Protein glycosylation: Nature, distribution, enzymatic formation, and disease implications of glycopeptide bonds. Glycobiology 12, 43-56.

Taguchi, G., Yazawa, T., Hayashida, N., Okazaki, M., 2001: Molecular cloning and heterologous expression of novel glucosyltransferases from tobacco cultured cells that have broad substrate specificity and are induced by salicylic acid and auxin. Europeean Journal of Biochemistry 268, 4086-4094.

VARKI, A., 2008: Sialic acids in human health and disease. Trends in Molecular Medicine $14,351-360$.

VITALE, A., 2001: Uncovering secretory secrets: Inhibition of endoplasmic reticulum (ER) glucosidases suggests a critical role for ER quality control in plant growth and development. The Plant Cell 13, 1260-1262. 
PAvoković D., KRSNiK-RAsol M.

Yamamoto, N., Kobayashi, H., Togashi, T., Mori, Y., Kikuchi, K., Kuriyama, K., ToKUJI, Y., 2005: Formation of embryogenic cell clumps from carrot epidermal cells is suppressed by 5-azacytidine, a DNA methylation inhibitor. Journal of Plant Physiology $162,47-54$. 